\title{
Correction: Phosphoglycerate mutase 1 promotes cancer cell migration independent of its metabolic activity
}

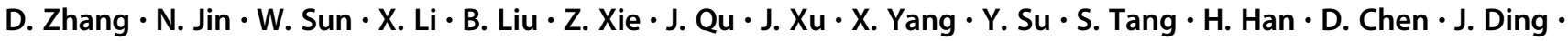 \\ M. Tan $\cdot$ M. Huang $\cdot$ M. Geng
}

Published online: 2 January 2020

๑) Springer Nature Limited 2020. This article is published with open access

\section{Correction to: Oncogene}

https://doi.org/10.1038/onc.2016.446

Following publication of this Article the Authors noted that a blot in Fig. 1c was misplaced and images were inadvertently duplicated in Supplementary Figs. S2 and S3.

The corrected Fig. 1 can be found below. The incorrect Supplementary files have been added to this Article. The scientific conclusions of this paper were not affected.
Open Access This article is licensed under a Creative Commons Attribution 4.0 International License, which permits use, sharing, adaptation, distribution and reproduction in any medium or format, as long as you give appropriate credit to the original author(s) and the source, provide a link to the Creative Commons license, and indicate if changes were made. The images or other third party material in this article are included in the article's Creative Commons license, unless indicated otherwise in a credit line to the material. If material is not included in the article's Creative Commons license and your intended use is not permitted by statutory regulation or exceeds the permitted use, you will need to obtain permission directly from the copyright holder. To view a copy of this license, visit http://creativecommons. org/licenses/by/4.0/. 
a

2935

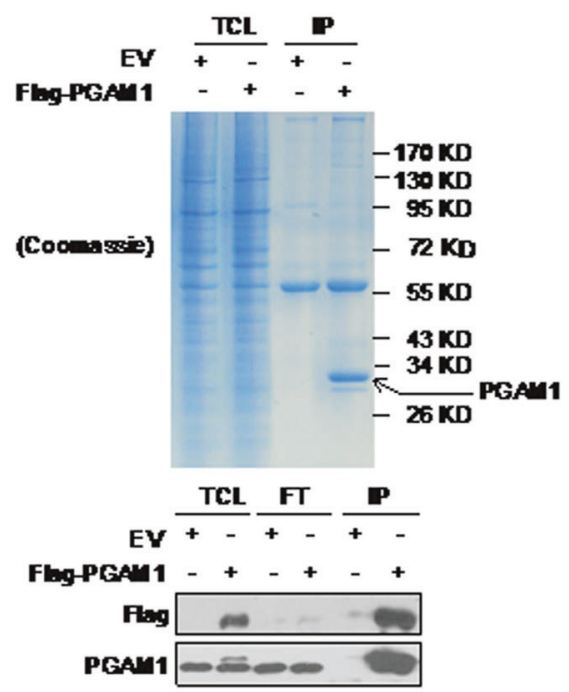

d
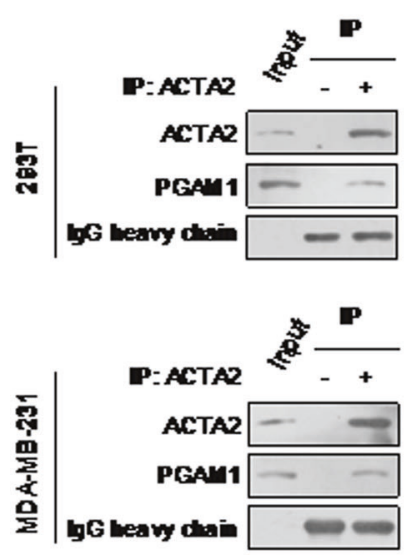

b

Genellane Prutin Score

PGAM1 7149

ACTA2 3157

PGAM4 1242

LOC440043 953

HIST1HZR 762

HLSTZHZBE 655

ACTA1 $\quad 589$

Ppp1ce 432

RCC1 232

HIST 1H3G $\quad 127$

H3F3A 123

WMB2 117

ELAM1 108

LYZ 100

H2AFY 99

MACA 94

HIST1H2AA 93

AKAP2 91

SFPQ 90

H2AFY 90

STUB1 क5

e

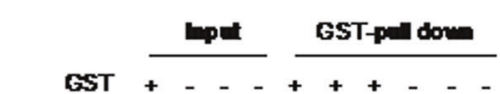

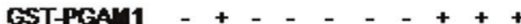

ACTA2 - + - - + - +

Proti-1 - - + - + + - +

ACTAO

Protie-1
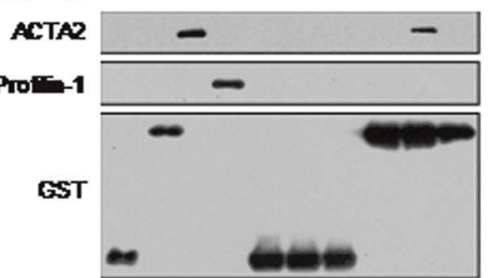

c
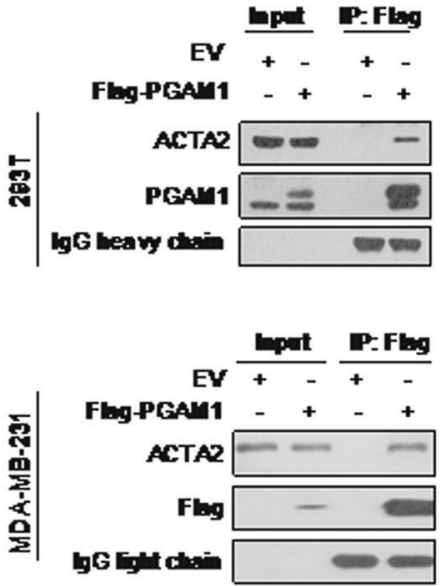

f

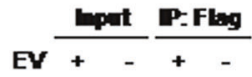

FlogACTA2 - + - +

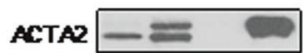

Pt:

PGAM1

ARP2 $-\infty-$

ARP3 $=$

cotis

Protie-1

$-\infty$

Gelsol

CAPZA1

GAPDH

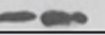

bG bith an:

20

Fig. 1 